\title{
ENDOGENOUS LIPOID PNEUMONIA WITH SPECIAL REFERENCE TO CARCINOMA OF THE LUNG
}

\author{
BY \\ S. DE NAVASQUEZ AND G. A. D. HASLEWOOD \\ From the Departments of Pathology and of Biochemistry and Chemistry, Guy's Hospital Medical School, London
}

(RECEIVED FOR PUBLICATION JULY 21, 1953)

Demonstrable fat in the lung due to the inhalation of mineral or vegetable oils or to fat embolism is well known. The occurrence of lipoid consolidation in which the fat was of endogenous origin and shown to consist largely of cholesterol and its esters was reported in a previous communication (De Navasquez, Trounce, and Wayte, 1951) and it was concluded that such fatty change was primarily the result of degeneration due to chronic injury. The present study was made to investigate the incidence and mechanism of such pathological changes and to test this conclusion.

\section{Materials and Methods}

The lungs from 42 necropsies on a wide variety of pulmonary diseases (Table I) were examined microscopically in paraffin and frozen sections with the usual histological methods of demonstrating fat. Nine cases of primary carcinoma of the lung of varied histological types were chosen because of the constant presence of fat in the affected lobe and because there was sufficient tissue both neoplastic and normal for chemical analysis. Samples of approximately $50 \mathrm{~g}$. of tissue were taken from the centre of the tumour and

TABLE I

INCIDENCE AND DEGREE OF LIPOID CHANGE SEEN MICROSCOPICALLY

\begin{tabular}{|c|c|c|c|c|c|c|}
\hline & & & $\begin{array}{c}\text { No. } \\
\text { of } \\
\text { Cases }\end{array}$ & $\begin{array}{l}\text { Intra- } \\
\text { cellular } \\
\text { Lipoid }\end{array}$ & $\begin{array}{l}\text { Extra- } \\
\text { cellular } \\
\text { Lipoid }\end{array}$ & $\begin{array}{c}\text { Lipoid } \\
\text { Pneumonia }\end{array}$ \\
\hline $\begin{array}{l}\text { Chronic passive } \\
\text { Infarct } \ldots \\
\text { Atelectasis ... } \\
\text { Emphysema } \\
\text { Bronchopneumor } \\
\text { Lobar pneumoni } \\
\text { Organizing pneur } \\
\text { Bronchiectasis } \\
\text { Fibrosis ... } \\
\text { Chronic abscess } \\
\text { Tuberculosis } \\
\text { Carcinoma }\end{array}$ & $\begin{array}{l}\text { ongest } \\
\ldots \\
\ldots \\
\ldots \\
\text { ria } \\
\text { nonia } \\
\ldots \\
\ldots \\
\ldots \\
\ldots \\
\ldots\end{array}$ & $\begin{array}{l}\text { ion } \\
\cdots \\
\cdots \\
\cdots \\
\cdots \\
\cdots \\
\cdots \\
\cdots \\
\cdots \\
\cdots \\
\cdots \\
\cdots\end{array}$ & $\begin{array}{r}4 \\
1 \\
2 \\
2 \\
12 \\
1 \\
1 \\
4 \\
1 \\
2 \\
3 \\
9\end{array}$ & $\begin{array}{l}++ \\
+++ \\
+ \\
+ \\
+ \\
++\end{array}$ & $\begin{array}{l}+ \\
+ \\
+++ \\
+++\end{array}$ & $\begin{array}{l} \pm \\
+- \\
++1\end{array}$ \\
\hline Total & $\ldots$ & $\ldots$ & 42 & & & \\
\hline
\end{tabular}

also from the periphery of the opposite lung, which appeared normal to the naked eye. This appearance was confirmed by subsequent microscopy. The tissue samples were washed in running water and freed from blood.

\section{RESULTS}

The amount of fat demonstrable histologically varied considerably in the different pathological conditions. It was not found in acute lesions such as bronchopneumonia and infarction, but was present in varying amounts in chronic conditions such as tuberculosis, where it was confined to the immediate vicinity of a caseous focus. In chronic bronchiectasis it occurred throughout the affected lung and in carcinoma it was constantly and abundantly present in that part of the lung peripheral to the tumour and in the tumour only where it was necrotic.

Most of the fat was anisotropic, and was free or extracellular as in the central necrotic foci of carcinoma (Fig. 1), intracellular and in macrophages contained in alveolar spaces unassociated with consolidation, or predominantly intracellular when associated with fibrosis as in the pneumonic area distal to a bronchial carcinoma (Fig. 2).

Chemical Estimation of Total Fat and total. CHOLESTEROL

The samples of lung and tumour tissue were at once dried in a desiccator in vacuo over sulphuric acid. After about a fortnight the samples were powdered, transferred to a large weighing bottle and dried for a further two to three weeks as before. The desiccator was then opened and a well-fitting lid at once placed over the weighing bottle which, after equilibration in the balance case, was weighed. To test the degree of desiccation, the drying and weighing process was repeated until constant weight was obtained. The weighing bottle was opened and the contents transferred to the extraction chamber of an all-glass Soxhlet apparatus. The emptied bottle was again closed and re-weighed. The difference was 


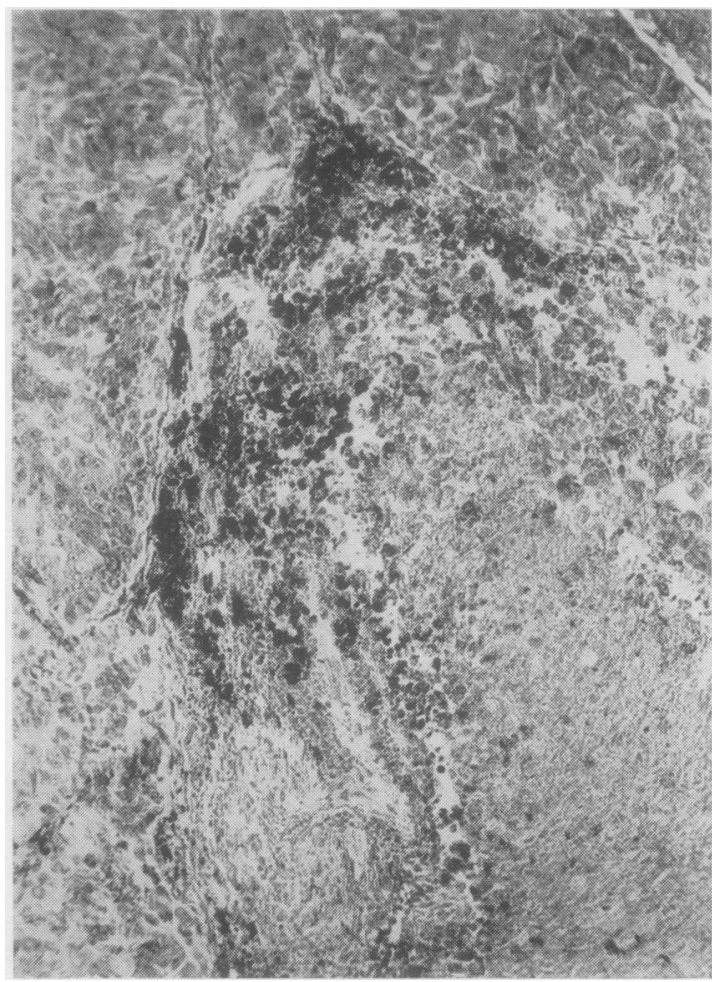

FIG. 1.-Photomicrograph of necrotic foci in carcinoma of lung showing extra-cellular lipoid. Frozen section stained Scharlach R. $\times 100$.

considered to be the weight of the sample of tissue dried to constant weight in vacuo over sulphuric acid at about $20-25^{\circ} \mathrm{C}$. Lung tissue is hygroscopic and it is possible to obtain a "dry weight" only under defined conditions. The tissue was extracted with ether in the Soxhlet apparatus for at least three days; it was then removed, re-powdered, and re-extracted with ether. It was found, in practice, that this process would extract almost all the fat obtainable with ether; the second extractioi: contributed about $1 \%$ of the total fat. Evaporation of the (filtered) ether extract, finally in vacuo, on a boiling water-bath, gave an amount of "total fat," the weight of which was not significantly diminished by drying in vacuo over sulphuric acid. The dry weights of lung and tumour tissue extracted ranged from 1.3 to $4.7 \mathrm{~g}$. A sample of the total fat weighing between 52 and $98 \mathrm{mg}$. was dissolved in $2 \mathrm{ml}$. ethanol with potassium hydroxide solution $(0.2 \mathrm{ml}$. of $40 \mathrm{~g}$. $100 \mathrm{ml}$. $)$ and heated at about 70 to $80^{\circ}$ for about 16 hours. The solution was then diluted with 1-2 ml. of ethanol, neutralized to phenolphthalein with acetic acid, and stirred with $10 \mathrm{ml}$. of a warm $1 \% \mathrm{w} / \mathrm{v}$ solution of digitonin in $90 \% \mathrm{v} / \mathrm{v}$ ethanol and water. After 24 hours the digitonide was collected on a weighed filter, washed with ethanol, a little water, then ether, and dried at $80^{\circ} \mathrm{C}$. The amount of cholestercl in the digitonide was calculated in the usual way.

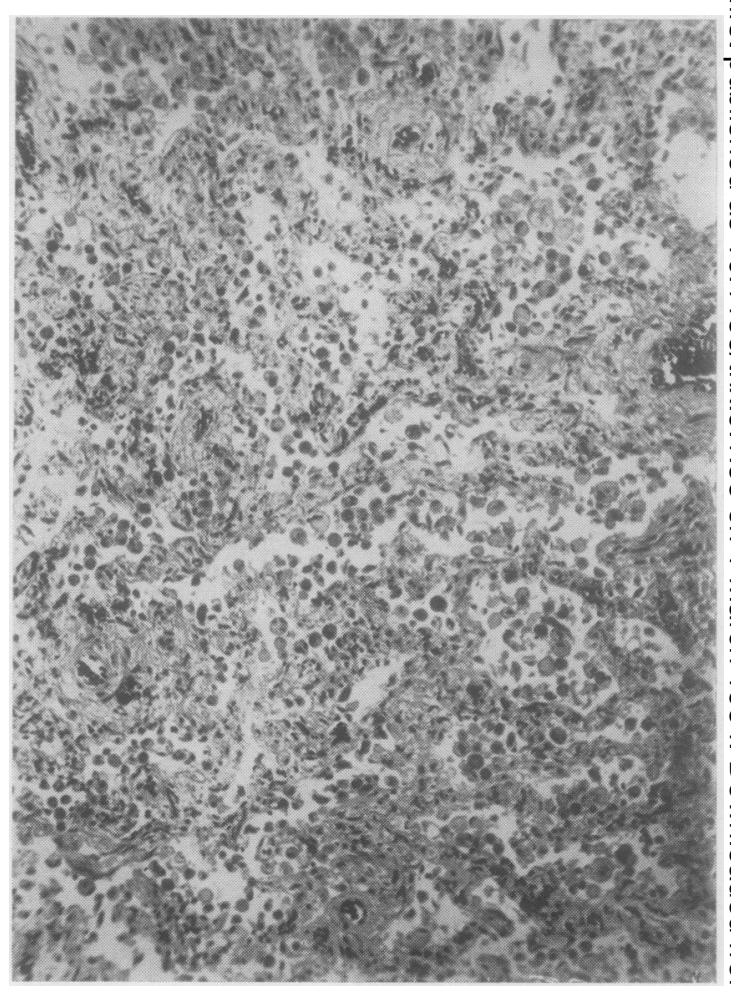

FIG. 2.-Photomicrograph of bronchiectatic lung showing intracellular cholesterol mainly in alveolar macrophages. Frozen section stained Scharlach R. 100

Results are given in Table II. From Table II it is clear that there is a significant difference $\underset{x}{\mathscr{D}}$ ( $P=0.02$ ) between the total fat contents of the lung and of the tumour, that there is no significant $\underline{3}$. difference between the total cholesterol contents of $\delta$ the fat from the two types of tissue, and no corre- 3 lation between the amounts of lung and tumour 윽 fat in any particular case.

TABLE II

TOTAL FAT AND CHOLESTEROL CONTENT OF FAT FROM N LUNG AND TUMOUR TISSUE IN NINE FATAL CASES OF LUNG CARCINOMA

\begin{tabular}{|c|c|c|c|c|}
\hline \multirow[t]{2}{*}{ Case No. } & \multicolumn{2}{|c|}{$\begin{array}{l}\text { Total Fat } \\
\text { (g. per } 100 \mathrm{~g} . \text { dry tissue) }\end{array}$} & \multicolumn{2}{|c|}{$\begin{array}{l}\text { Total Cholesterol } \\
\text { (g. per } 100 \mathrm{~g} . \text { dried fat) }\end{array}$} \\
\hline & Lung & Tumour & Lung & Tumour \\
\hline $\begin{array}{l}1 \\
2 \\
3 \\
4 \\
5 \\
6 \\
7 \\
8 \\
9\end{array}$ & $\begin{array}{r}8 \cdot 5 \\
7 \cdot 9 \\
7 \cdot 7 \\
5 \cdot 5 \\
7 \cdot 8 \\
10 \cdot 3 \\
6 \cdot 2 \\
15 \cdot 1\end{array}$ & $\begin{array}{r}12.4 \\
12.1 \\
7.5 \\
11.1 \\
9.4 \\
16.4 \\
10.9 \\
19.7 \\
18.3\end{array}$ & $\begin{array}{l}20.9 \\
21.8 \\
19.0 \\
12.3 \\
\overline{16.4} \\
27.8 \\
23.0 \\
10.5\end{array}$ & $\begin{array}{l}24 \cdot 5 \\
21 \cdot 0 \\
25 \cdot 1 \\
25 \cdot 4 \\
26 \cdot 5 \\
17 \cdot 2 \\
19 \cdot 8 \\
10 \cdot 0 \\
26.4\end{array}$ \\
\hline $\begin{array}{l}\text { Mean } \\
\text { S.E. of mean }\end{array}$ & $\begin{array}{r}8.63 \\
\therefore 1.05\end{array}$ & $\begin{array}{r}13.09 \\
+1.38\end{array}$ & $\frac{18 \cdot 96}{-}$ & 21.77 \\
\hline
\end{tabular}




\section{Discussion}

INCIDENCE. - Microscopically visible fat appeared to be confined to lesions which were chronic in the sense that they were slow in origin and of long standing; such lesions were of a degree of severity short of necrosis. In the tumours fat became obvious only in areas of degeneration. Apart from this exception, lipoid was demonstrable as intra- and extracellular " cholesterol" in bronchiectasis, fibrosis, and chronic abscess; it was maximal in the lung distal to bronchial carcinoma.

OrIGIN OF THE LIPOID.-Chemical analysis of the normal lung tissue gave for eight cases an average value of total fat of $8.63 \mathrm{~g}$. per $100 \mathrm{~g}$. of dry tissue, of which, on an average, $18.96 \%$ was total cholesterol. This compares with an average total fat in six cases of 5.2 g. per $100 \mathrm{~g}$. of dry tissue found by Armin and Grant (1951). Since the lung tissue analysed was taken from the periphery and contained only a few sparse bronchioles, it is a reasonable assumption that it was mainly of "parenchymatous" origin and largely from alveoli free from blood. Moreover, some of the fat seen was extracellular, indicating either an extrusion from damaged but still viable alveolar cells or that it represented the lipoid remnants of such cells. The latter view is more probable, as no lipoid-containing cells other than macrophages, which could be identified by their content of carbon, were seen.

Association with Carcinoma.-The similarity in the percentage composition of cholesterol in the fat of normal lung and carcinoma and the invariable lipoid consolidation in the lung distal to the tumour, which was free from neoplasm, may be explained in two ways. First, the lipoid may have been derived from the tumour and aspirated distally, where it was engulfed by macrophages which accumulate in collapsed alveoli; or, secondly, it may have been derived from degenerating lung injured either by infection or by nutritional disturbance caused by the tumour. The second view is favoured by the fact that the degree of lipoid change was not correlated with the degree of necrosis in the tumour, which is the only circumstance likely to lead to liberation of free lipoid. Furthermore, the lipoid change was distributed widely throughout the lung supplied by the bronchus involved.

Pathogenesis. - There was no significant correlation between the fairly constant fat content as determined by chemical analysis and that revealed by microscopy. In fact, the amount of demonstrable fat seen varied widely in different pathological states but appeared greater both in the neoplasm and in the affected lung when these tissues appeared to be disintegrating, and was best seen in the early stages of cellular degeneration in the central foci of a carcinoma and becoming less and less with the onset of complete necrosis. It would appear therefore that fatty change represents only a phase in cell injury, an intermediate metabolic state which occurs early and disappears with cell death. What remains of extracellular fat is phagocytosed by macrophages, the local persistence of which is responsible for the appearance of lipoid pneumonia.

\section{SUMMARY}

The incidence of endogenous lipoid pneumonia is described.

The pathogenesis of the condition is discussed and it is concluded that it represents fatty change of the pulmonary parenchyma, the result of chronic injury.

\section{REFERENCES}

Armin, J., and Grant, R. T. (1951). Clin. Sci., 10, 441.

De Navasquez, S. J., Trounce, J. R., and Wayte, A. B. (1951). Lancet, 1, 1206. 